\title{
A szívinfarktus miatt kezelt betegek ellátásának és prognózisának fontosabb adatai. Nemzeti Szívinfarktus Regiszter 2018
}

\author{
Jánosi András \\ Gottsegen György Országos Kardiológiai Intézet, Budapest \\ Levelezési cím: \\ Prof. dr. Jánosi András, szakmai vezető, Nemzeti Szívinfarktus Regiszter \\ Tel.: 299-8100/513 \\ E-mail: regiszter@kardio.hu
}

\begin{abstract}
A Nemzeti Szívinfarktus Regiszter (NSZR) a hazai egészségügyi adatbázisok egyik meghatározó tényezőjeként müködik. 2015 decemberében az adatbázis anonimizált állományát integráltuk az „Országos egészségmonitorozási és kapacitástérkép adatbázis- és alkalmazásfejlesztés” (TÁMOP 6.2.3.-12/1-2012-0001) programba, amely Magyarország legnagyobb egészségügyi adatbankja. Az NSZR tevékenységének törvényi szabályozása óta - évente - összefoglalja az ellátás fontosabb adatait és azt megküldi a betegellátást végző intézeteknek és az irányító hatóságoknak (Államtitkárság, Országos Tisztiföorvos, ÁEEK), valamint közli a Cardiologia Hungaricában.
\end{abstract}

\section{Adminisztratív adatok}

A KSH adatai szerint a heveny szívinfarktusban meghalt betegek száma az elmúlt négy évben nem változott, ugyanakkor a korábbi időszakhoz képest jelentősen csökkent (1. ábra).

A 2018. évi adatot 2019 augusztusában közlik.

\section{A Nemzeti Szívinfarktus Regiszterben rögzített betegek és események száma}

2018. december 31-én 92 aktív centrum szolgáltatott adatokat, a rendeletnek megfelelően minden olyan aktív egészségügyi ellátóhely, ahol szívinfarktus diagnosztizálnak, illetve kezelnek. Az NSZR müködését szabályozó rendeletnek megfelelően jelenleg 92 centrum szolgáltat adatot, minden olyan ellátó hely, ahol szívinfarktus miatt kezelnek betegeket illetve szívinfarktust diagnosztizálnak. A Regiszter adatokat kap fekvőbeteg-intézetekből, illetve patológiai osztályoktól. Az NSZR adatbázisában, 2019 januárjában 93321 be-

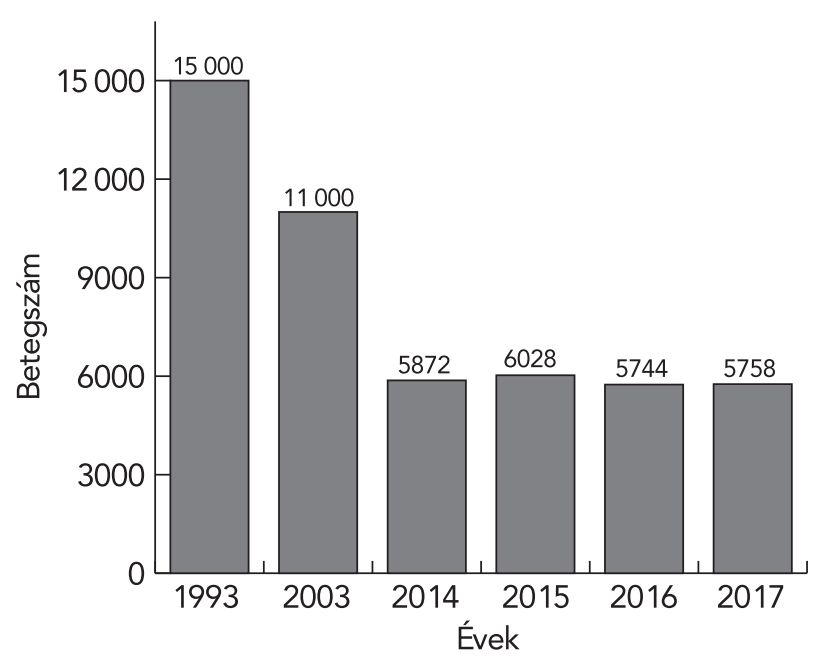

1. ÁBRA. AMI diagnózissal meghalt betegek száma - KSH. A 2018. évire vonatkozó adat 2019 augusztusában lesz hozzáférhető 


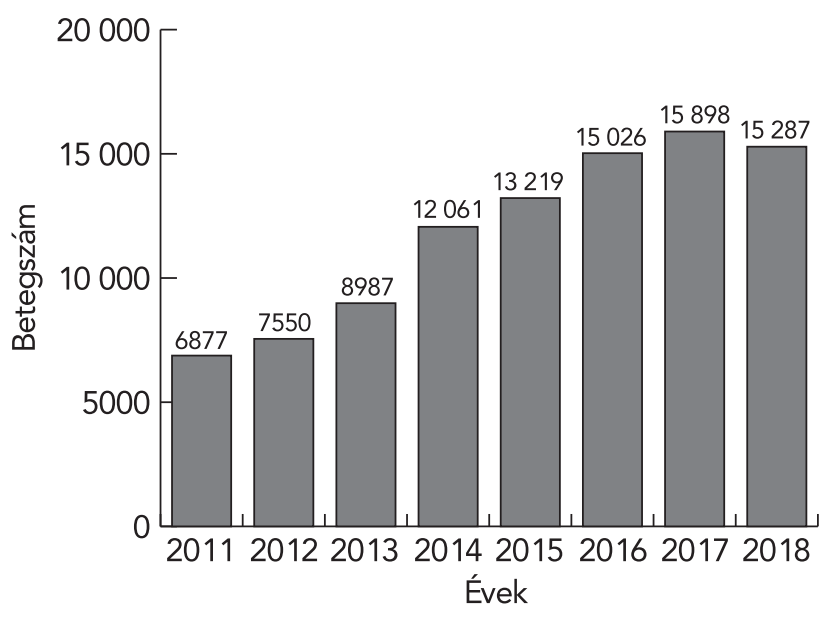

2. ÁBRA. A Nemzeti Szívinfarktus Regiszterben regisztrált betegek száma

teg 101609 eseményével kapcsolatban rendelkeztünk adatokkal. Az évente regisztrált betegek számát az 2 . ábrán mutatjuk be.

\section{A szívinfarktus „fő́diagnózissal” kórházban kezelt betegek száma - OEP/NEAK}

Az OEP/NEAK adatbázisa szerint 2015 évben akut miokardiális infarktus (AMI) fődiagnózis (I21-I23) megjelöléssel 14 868, 2016-ban 15 179, 2017-ben 15 186, 2018-ban 15082 beteg részesült kórházi kezelésben. A kezelést indokoló fődiagnózisként szereplő AMI (I21I23) számának tekintetében lényeges változás az évek során nem figyelhető meg (1. táblázat).

1. TÁBLÁZAT. A kezelést indokoló fődiagnózisként szereplő AMI-k (I21-I23) száma

\begin{tabular}{|c|c|}
\hline Év & Betegek száma \\
\hline 2007 & 15993 \\
\hline 2008 & 16120 \\
\hline 2009 & 16686 \\
\hline 2010 & 14605 \\
\hline 2011 & 14677 \\
\hline 2012 & 14971 \\
\hline 2013 & 15343 \\
\hline 2014 & 15590 \\
\hline 2015 & 14868 \\
\hline 2016 & 15179 \\
\hline 2017 & 15186 \\
\hline
\end{tabular}

A finanszírozott és a Nemzeti Szívinfarktus Regiszterben (NSZR) rögzített betegek aránya

Megvizsgáltuk, hogy mennyire teljes az NSZR adatbázisa. A megítéléshez regisztrált/finanszírozott események arányának alakulását vettük alapul. Adataink alapján a Regiszter adatbázisának teljessége folyamatosan nő: 2013-ban 51\%, 2014-ben 67\%, 2015-ben 71,3\%, 2016-ban 87,9\%, 2017-ben 91,74\%, 2018-ban $88,56 \%$ volt. (A 2018. évi adat valószínüleg tovább nő, mivel a centrumok a hiányzó események pótlására szolgáló felkérést 2019 márciusában kapják meg). Tekintettel arra, hogy az infarktusos betegek döntö hányada szívkatéteres centrumban kerül ellátásra, a 2. táblázatban az egyes szívkatéteres centrumokra lebontva vizsgáltuk a kezelt (az OEP által finanszírozott) és a regiszterben rögzített betegek arányát. Látható, hogy a rögzítési fegyelem a centrumok között jelentősen eltér, de többségében eléri vagy meghaladja a 90\%-ot.

\section{A szívkatéteres centrumokban finanszíro- zott és a regisztrált események száma}

A regisztráció teljessége érdekében folyamatosan tájékoztatjuk a centrumokat, hogy mennyire teljes az általuk kezelt betegek regisztrációja, ennek kapcsán megküldjük azoknak a betegeknek a TAJ-számát, akiknek kezelését az OEP finanszírozta, de nem szerepelnek az NSZR adatbázisában.

\section{Az NSZR-ben rögzített betegek esetén a különböző típusú szívinfarktusok (ST-elevációval járó, nem ST-elevációval járó) gyakorisága}

A 2018. évben regisztrált infarktusos események 41,32\%-a STEMI, 58,68\%-a NSTEMI diagnózissal került rögzítésre.

\section{Az NSZR-ben rögzített ST-elevációval járó szívinfarktusos betegek (STEMI) esetén szívkatéteres centrumba került betegek aránya, a centrumba jutás módja (primer vs. szekunder transzport) a primer perkután koronária-intervenció (PPCl) aránya}

A regisztrált betegek $62,08 \%$-a volt férfi. A STEMI miatt kezelt betegek átlagos életkora 64,7 év volt. A STEMI-események 93,03\%-át szívkatéteres centrumban kezelték (egy betegnek adott évben több 


\begin{tabular}{|c|c|c|c|c|c|}
\hline \multirow[t]{2}{*}{ Kórház } & \multicolumn{5}{|c|}{ Finanszírozásra jelentett betegek rögzítési aránya (\%) } \\
\hline & 2014 & 2015 & 2016 & 2017 & 2018 \\
\hline Bajcsy & 79,0 & 94,2 & 83,3 & 56,8 & 90,9 \\
\hline Balatonfüred & 62,7 & 100,0 & 100,0 & 95,0 & 97,6 \\
\hline BIK & 31,6 & 72,6 & 62,7 & 78,2 & 90,7 \\
\hline Debrecen Kard. & 91,0 & 75,6 & 62,8 & 97,0 & 96,3 \\
\hline GOKI & 75,2 & 97,0 & 92,6 & 89,5 & 93,1 \\
\hline Győri Megyei Kh. & 57,0 & 93,6 & 96,3 & 83,1 & 74,9 \\
\hline Gyula & 60,3 & 40,1 & 96,0 & 88,5 & 94,8 \\
\hline Honvéd Kh. Bp. & 34,8 & 100,0 & 100,0 & 77,9 & 68,6 \\
\hline Kaposvár & 45,5 & 91,5 & 91,6 & 68,4 & 93,6 \\
\hline Kecskemét & 95,4 & 100,0 & 82,0 & 96,1 & 91,8 \\
\hline Miskolc & 49,6 & 69,7 & 99,5 & 99,5 & 99,2 \\
\hline Nyíregyháza & 96,9 & 95,9 & 96,9 & 93,9 & 94,4 \\
\hline PTE Szívgyógyászat & 73,5 & 96,9 & 99,8 & 92,8 & 95,5 \\
\hline SE, Szív- és Érgyógyászati Klinika & 68,1 & 100,0 & 98,7 & 99,1 & 98,9 \\
\hline Szeged Kard. & 39,6 & 88,6 & 78,6 & 89,8 & 84,9 \\
\hline Székesfehérvár & 68,4 & 77,0 & 97,7 & 88,1 & 88,3 \\
\hline Szolnok & 76,1 & 86,9 & 98,1 & 94,7 & 85,5 \\
\hline Szombathely & 63,2 & 93,5 & 95,0 & 76,9 & 85,2 \\
\hline Zalaegerszeg & 84,2 & 100,0 & 98,9 & 99,2 & 99,7 \\
\hline
\end{tabular}

eseménye is lehet, ezért célszerủ az eseményeket vizsgálni). A primer transzport aránya $69,35 \%$ volt. A kóros koronarográfiájú betegek $93,6 \%$-ánál primer perkután koronária-intervencióra ( $\mathrm{PPCl}$ ) került sor. Prehospitális trombolízis a betegek 0,26\%ában történt, míg a kórházban a gyógyszeres vérrögoldó beavatkozásra a betegek 0,4\%-ában került sor.

\section{Az NSZR-ben STEMI-diagnózissal rögzített és $\mathrm{PPCl}-k e z e l e ́ s b e n$ részesített beteg esetén az érmegnyitás ideje, ezen belül az ajtó-tú idő}

A szívkatéterezés 92,3\%-ban radiális behatolásból történt. A szívkatéteres centrumba felvett betegek esetén a panasz kezdete és az infarktusért felelős ér megnyitása közötti időt a regisztrált betegek $73,4 \%$-ánál ismerjük. A panasz kezdetétől a szívkatéteres laboratóriumba érkezésig idő mediánja 4 óra 30 perc volt. $A z$ ajtó-tü idő medián értéke 40 perc. A késlekedési idő döntő része tehát a prehospitális időszakra esik, illetve az áthelyezéssel kapcsolatos. A betegek $77,1 \%$-ánál az ér megnyitására 12 órán belül került sor, ez jelentős $20 \%$-os javulás az előző évhez képest. Az érmegnyitás kapcsán a betegek $96,6 \%$-a kapott stentet. A beültetett stentek $89,42 \%$-a DES volt. Szövődmény az indexesemény kórházi kezelése során beavatkozások 1,34\%ánál fordult elö.

\section{Az NSZR-ben rögzített nem ST-eleváció- val járó szívinfarktusos betegek (NSTEMI) esetén a szívkatéteres centrumba került betegek aránya, és ellátási módja}

A vizsgált évben az infarktus miatt kezelt betegek több mint a fele $(58,56 \%)$ NSTEMI miatt került ellátásra. A betegek átlagos életkora 69,5 év volt. A kezelt betegek többsége férfi volt $(59,4 \%)$. Az NSTEMI diagnózissal kezelt betegek $84,1 \%$-a szívkatéteres centrumban kapott ellátást, 57,3\%-nál $\mathrm{PCl}$ történt. A szívkatéterezést a beavatkozások 93,6\%-ában radiális behatolásból végezték. Az érmegnyitás során a betegek $93,4 \%$-a kapott stentet, a beültetett eszközök $91,32 \%$ DES volt. Szövődményt a beavatkozások 2,4\%-ában rögzítettek.

\section{Hová távozott a beteg, arról az osztályról ahová először felvették?}

Az indexeseményt követően a betegek további sorsát a 3.a, illetve a 3.b ábra mutatja.

\section{A távozáskor alkalmazott gyógyszeres kezelés}

A kórházi kezelés alatt alkalmazott, illetve a távozáskor javasolt gyógyszerek gyakoriságát \%-os megoszlásban a 4. ábra mutatja. 
a)

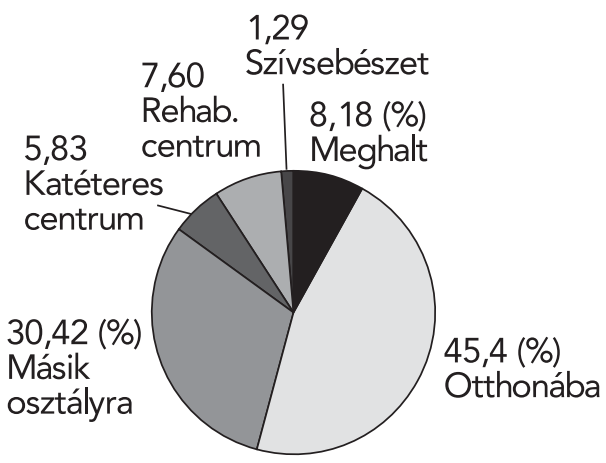

b)

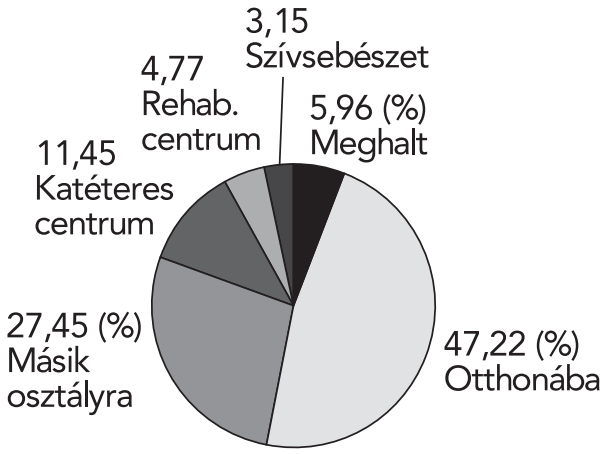

3. ÁBRA. STEMI (a); NSTEMI (b)

\section{A STEMI, illetve NSTEMi diagnózissal kezelt betegek kórházi, 30 napos és 1 éves halálozása}

Az adatokat a 3. táblázat tartalmazza. Az PCl-kezelésben részesült betegeknek - mindkét típusú infarktus esetén -, mind a 30 napos, mind az 1 éves időpontban lényegesen jobb volt a prognózisa.

\section{Intézeti rehabilitációban részesült betegek regisztere}

Folyamatos a fekvőbeteg-rehabilitációban részesített betegek regisztrációja, amely képet ad az intézeti rehabilitáció fontosabb adatairól. Jelenleg 6005 beteg fekvőbeteg rehabilitációjával kapcsolatos adatok sze-

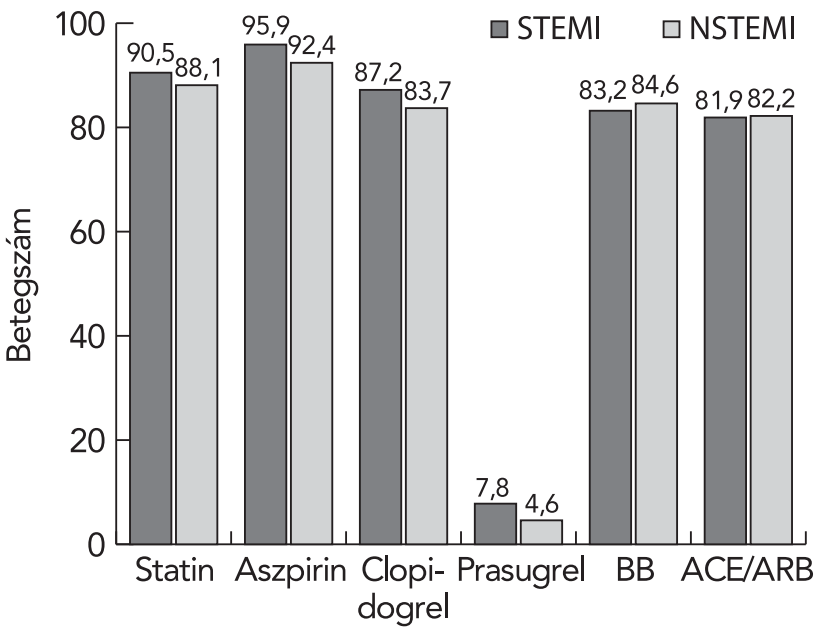

4. ÁBRA. A kórházi kezelés alatt alkalmazott, illetve a távozáskor javasolt gyógyszerek gyakorisága \%-os megoszlásban

repelnek az adatbázisban. Az informatikai rendszer fejlesztése 2018-ban megtörtént, így az akut ellátás és a rehabilitációs kezelés adatai összekapcsolhatók és együtt elemezhetők.

\section{Szekciós adatok adatbázisa}

Az NSZR-ről szóló miniszteri rendelet a patológiai osztályok számára is előírja a boncolás során talált heveny infarktusos esetek adatainak regisztrációját. Az informatikai háttér jelenleg folyamatban lévő fejlesztésével ezen információk is egységesen kerülnek tárolásra és lekérdezhetők. Jelenleg 2014. január 1-től 6018 patológiai adatlappal rendelkezünk, ezek közül 4669 olyan infarktusos halálesettel kapcsolatos, amihez nem kapcsolódik kórházi esemény, illetve a Regiszter adatbázisában nem szerepel.

\section{Közlemények 2018-évben}

1. El-Meouch Nedim M, Ferenci T, Jánosi A. A dohányzás hatása a szívinfarktus után túlélésre - dohányzási paradoxon Magyarországon? Orvosi Hetil 2018; 159 (14): 557-565.

3. TÁBLÁZAT. Az NSZR-ben rögzített infarktusos betegek kórházi, 30 napos és 1 éves halálozása

\begin{tabular}{|l|c|c|c|c|c|c|c|c|c|c|}
\hline & \multicolumn{9}{|c|}{ STEMI } & \multicolumn{4}{c|}{ NSTEMI } \\
\hline & 2014 & 2015 & 2016 & 2017 & 2018 & 2014 & 2015 & 2016 & 2017 & 2018 \\
\hline Kórházi halálozás (\%) & 8,3 & 8,4 & 9,6 & 9,3 & 9,9 & 6,6 & 7,4 & 7,8 & 8,7 & 7,6 \\
\hline 30 napos halálozás (\%) & 13,2 & 12,9 & 13,5 & 13,5 & 13,8 & 11,3 & 11,8 & 12 & 13 & 12,1 \\
\hline PCI történt & 8,8 & 9,1 & 9,8 & 10,1 & 10,5 & 5,1 & 5,8 & 6,5 & 6,5 & 6,8 \\
\hline 1 éves halálozás (\%) & 21,4 & 19,9 & 20,4 & 20,2 & - & 23,3 & 23 & 24,9 & 25,1 & - \\
\hline PCI történt & 15,0 & 15,1 & 15,2 & 15,6 & - & 12,9 & 14,2 & 15 & 14,9 \\
\hline
\end{tabular}


2. Komócsi A, Aradi D, Szűk T, et al. Comparison of Platelet Function Guided Versus Unguided Treatment With $\mathrm{P}_{2} \mathrm{Y}_{12}$ Inhibitors in $\mathrm{Pa}$ tients With Acute Myocardial Infarction (from the Hungarian Myocardial Infarction Registry). Am J Cardiol 2018; 121: 1129-37. doi. org/10.1016/j.amjcard.2018.01.032

3. Jánosi $A$, Ferenci $T$, Ofner $P$, et al. Does gender have prognos tic value among patients with myocardial infarction? Analysis of the data from the Hungarian Myocardial Infarction Registry. Journal of Women's Health 2018; 27. doi: 10.1089/jwh2017.6763

4. Jánosi A, Erdős G, Pach PF, Forster T, Ungi I, Ofner P, Andréka P. A teljes ischaemiás idő prognosztikus jelentősége az ST-elevációval járó szívinfarktus miatt kezelt betegekben. Orv Hetil 2018; 159(27) $1112-1120$

\section{Előadások 2018-évben}

1. Jánosi A. Akut miokardiális infarktus epidemiológia, ellátás, prog nózis. Nemzeti Szívinfarktus Regiszter 2007-2017. Debreceni Kardiológiai Napok. Debrecen, 2018.02.28-2018.03.03

2. Jánosi A, Veldre G, Ofner P, Andréka P, Ferenci T. Az ST-elevációval járó szívinfarktus miatt kezelt betegek klinikai jellemzői, ellátása és prognózisa Észtországban és Magyarországon. MKT Balatonfüredi Kongresszusa, Balatonfüred 2018. Cardiologia Hungarica 2018; 48: C2

3. Jánosi A. Hazai kardiovaszkuláris mortalitási adatok: öröm és üröm. MKT Balatonfüredi Tudományos Ülése. EGIS Szimpózium. Balatonfüred, 2018. 05.10-12.
4. Jánosi A. Szívinfarktusos betegek ellátásának adatai - 2017.Új diagnosztikus kritériumok - 2018. IV. Pécsi Kardiológiai prevenciós és rehabilitációs kongresszus. Pécs, Kodály központ. 2018. szeptember 27-29.

5. Jánosi A. Szívinfarktus Regiszter. VI. Budapesti Kardiológiai Napok. Budapest, 2018. november 16-17.

6. Jánosi A. Az AMI szekunder prevencióját jellemző hazai és svéd mutatók közötti különbségek. VI. Budapesti Kardiológiai Napok. Bu dapest, 2018. november 16-17.

7. Póth A, Zorándi Á. A panasz kezdet és az ér megnyitásának ideje a STEMI miatt kezelt betegeknél-Nemzeti Szívinfarktus Regiszter adatainak elemzése. MKT Balatonfüredi Tudományos Ülése. EGIS Szimpózium. Balatonfüred, 2018. 05.10-12.

\section{Köszönetnyilvánítás}

A szerző ezúton mond köszönetet Póth Anikó vezető adminisztrátornak, Zorándi Ágnes statisztikai munkatársnak, Sinka Erika vezető kontrollernek, Adamik Marianna, Bradák Anna, Gál Judit, Berecz Bea kontrollereknek.

A kézirat szerkesztőségbe érkezett 2019. március 11-én. 